\title{
SOME TESTS ON THE COMPACTIBILITY AND HARDNESS AFTER GOMPACTION OF DIFFERENT TYPES OF SNOW
}

\author{
By B. H:son Ager* \\ (Forskningsstiftelsen Skogsarbeten, Stockholm, Sweden)
}

\begin{abstract}
Compaction of different types and mixtures of snow including snow collected from the natural snow cover and waste from an ice milling machine, was carried out in a cold room with a small model compactor. Density, cone hardness and shear strength were measured, generally 24 hours after compaction, for specimens compacted in different ways. When the snow was compacted to maximum, densities between 0.55 and $0.60 \mathrm{~g} . / \mathrm{cm} .^{3}$ were achieved, except for mixtures including more than one third new snow for which densities were lower. For snow collected from the natural cover the highest hardness values after compaction were found for new snow and for mixtures including more than $5^{\circ}$ per cent of new snow or fine-grained granular snow. The maximum hardness was obtained with specimens prepared from fine-grained mill waste.

The influence of temperature on density and hardness was also studied.
\end{abstract}

RÉsumÉ. Quelques tests sur le compactage et la dureté après compactage de différents types de neige. On a procédé dans une chambre froide avec un compacteur petit modèle, au compactage de différents types et mélanges de neige recueillis dans la couverture de neige naturelle. La densité, la dureté determinée au cône et la résistance au cisaillement ont été mesurées généralement 24 heures après le compactage pour des spécimens compactés de façons différentes. Lorsque la neige était compactée au maximum des densités allant de 0,55 à $0,60 \mathrm{~g} / \mathrm{cm}^{3}$ étaient obtenues, sauf dans le cas des mélanges comprenant plus d'un tiers de neige nouvelle pour lesquels les densités étaient plus faibles. Les plus hautes valeurs de dureté après le compactage ont été trouvées pour de la neige récente et pour des mélanges comprenant plus de $50 \%$ de neige récente ou de neige à granulation très fine.

L'influence de la température sur la densité et la dureté a également été étudiée.

Zusammenfassung: Einige Versuche über die Verdichtbarkeit und über die Härte nach Verdichtung von verschiedenen Schneearten. Die Verdichtung verschiedener Arten und Mischungen von Schnee, der aus der natürlichen Schneedecke entnommen war, wurde in einer Kältekammer mit einem kleinen Modell-Verdichter vorgenommen. Dichte, Härte und Scherfestigkeit wurden gewöhnlich 24 Stunden nach der Verdichtung an Proben von verschiedenem Verdichtungsgrad gemessen. Bei einer maximalen Verdichtung des Schnees wurden Dichten zwischen 0,55 und $0,60 \mathrm{~g} / \mathrm{cm}^{3}$ erreicht, ausser bei Mischungen, die mehr als ein Drittel Neuschnee enthielten, deren Dichte geringer war. Die grössten Härtewerte nach der Verdichtung wurden für Neuschnee und für Mischungen, die mehr als $50 \%$ Neuschnee oder feinkörnigen Schnee enthielten gefunden.

Ausserdem wurde der Einfluss der Temperatur auf Dichte und Härte untersucht.

\section{INTRODUCTION}

Under the sponsorship of Forskningsstiftelsen SDA, Skogshögskolan and the Swedish Army, a series of investigations has been carried out on the preparation and use of snow roads in Sweden. One of the questions of interest was the influence of snow type on the density and strength of compacted snow, i.e. the road quality obtained in the early part of the winter when the snow contains a comparatively large percentage of fresh or only slightly metamorphosed snow, and in late winter when the snow cover consists of a greater part of highly metamorphosed snow. To study this problem by repeated compaction with full-scale field equipment during a winter would be very expensive, and the many variables encountered under natural conditions would make it very difficult to discern the influence of different types of snow.

In I96o and I96r the author had an opportunity to work with the Snow and Ice Section of the Division of Building Research, National Research Council of Canada. During that period it was possible to carry out laboratory tests on compaction of different types of snow, and to fit them in with the over-all test program begun in Sweden. The results of these investigations are recorded in this paper.

A comprehensive summary of other investigations on snow compaction can be found in

* This work was done while the author held a post-doctorate fellowship with the Snow and Ice Section, Division of Building Research, National Research Council, Ottawa, Canada, r960-61. 
the report of a conference organised by Massachusetts Institute of Technology in February r 962 (Kingery, r963).

\section{Test Procedure}

Compaction was carried out with a small compactor designed and described by Williams (1958). The cylinders in which the snow was compacted were $86 \mathrm{~mm}$. high and $60 \mathrm{~mm}$. in diameter, having a volume of about $243 \mathrm{~cm} .^{3}$.

Two methods of compaction were used. One was to compact the snow in 2-cm. layers with five blows from a fall height of $10 \mathrm{~cm}$. This gave a density value very close to the maximum for this type of compression (Williams, 1958), and is for convenience called "maximum compaction" in this report. The other method was to fill the cylinder by pouring the snow gently into it and compact it by dropping the weight once from a height of $10 \mathrm{~cm}$. This gives, according to the author's experience, a density equal to that obtained by one pass with simple field equipment such as light rollers or drags. It is called "one-blow compaction" in this report. It gives a slight density gradient in the specimen, but this was neglected because the main object of the test was to make a comparison of the density values obtained with different types of snow.

The compacted specimens were generally allowed to harden for about $24 \mathrm{hr}$. The density, "cone hardness", and shear strength of the specimens were then determined. Density was determined by weighing the specimen and measuring its height. Cone hardness was measured by observing the penetration of a 30-degree I0o-g. cone (Fig. I) dropped from a height of $30 \mathrm{~mm}$. From the penetration, the hardness $H \mathrm{in} \mathrm{kg} . / \mathrm{cm} .{ }^{2}$ was calculated by using the formula suggested by Angervo (195I):

$$
H=\frac{L(D+P)}{0 \cdot 075^{1} 6 P^{3}}
$$

where $L$ is the weight of the cone in $\mathrm{kg}$., $D$ is the fall height in $\mathrm{cm}$. and $P$ is the penetration in $\mathrm{cm}$. Shear strength was measured with a shear vane and a torque wrench (Fig. 2) operated

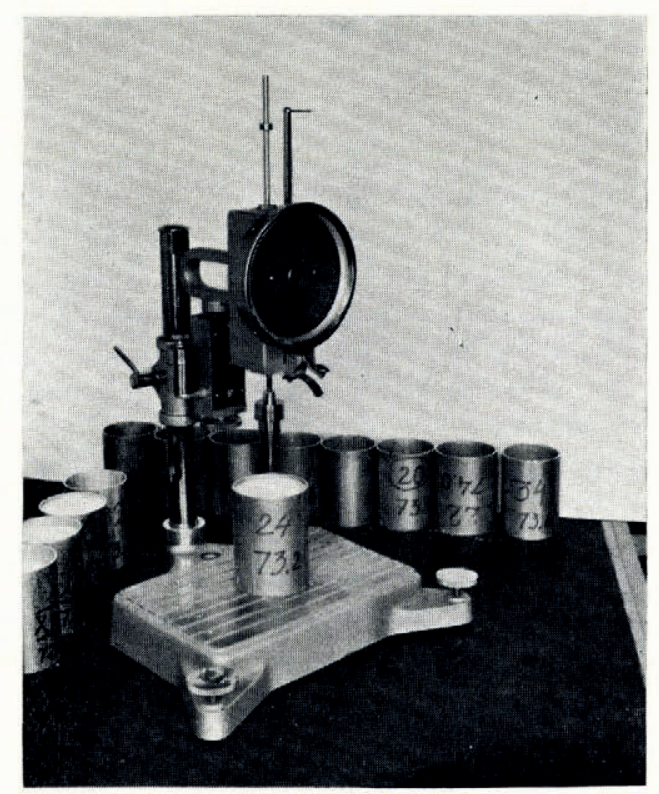

Fig. I. Drop cone used for hardness test 
manually. Torque was increased at a rate of approximately $\mathrm{I} \mathrm{kg} . \mathrm{cm}$. $/ \mathrm{sec}$. Three different sizes of vanes were used initially, all having a ratio of height to width of $2: \mathrm{I}$. The sizes were:

Code

\begin{tabular}{lrr} 
& & \multicolumn{1}{c}{$\mathrm{cm}^{2}$} \\
Large & (B) & I9.58 \\
Medium & (M) & I0.86 \\
Small & (S) & $5 \cdot 96$
\end{tabular}

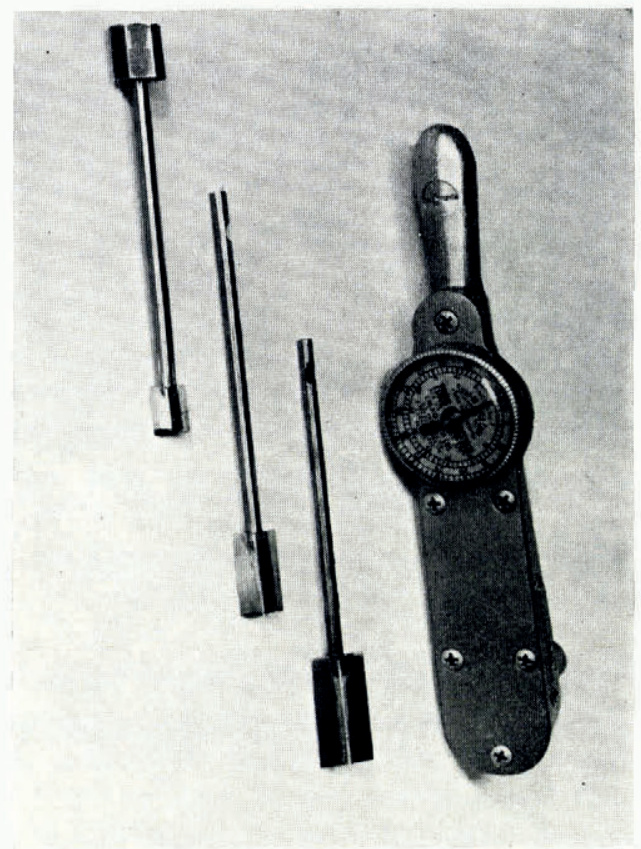

Fig. 2. Shear vanes and torque wrench

Some of the samples had a shear strength exceeding both the strength of the smallest vane and the highest value that could be read on the torque wrench. In order to cover a greater range of strengths, the height of the smallest vane was reduced by 40 per cent. The ratio of height to width was then $I_{1} 2: I_{\text {and }}$ the shear cylinder area $4 \cdot 34 \mathrm{~cm}$. This vane has the symbol S II.

\section{Description of Snow Used in the Tests}

Most of the snow used in the tests was collected from the lawn outside the Division of Building Research, Ottawa, and was taken into a cold room for storage at a temperature of $-9 \cdot 5^{\circ} \mathrm{C}$. Waste from an ice milling machine was also used. The snow was kept in cardboard boxes lined with plastic sheets, and was always gently broken up and stirred before being placed in the cylinders. Table I describes the snow used in each test series.

The depth hoar kept its microscopic character of "ordinary" depth-hoar snow even after I oo days of storage. Inspection with a microscope, however, showed that the edges of the snow crystals became more and more rounded with time, tending towards a coarse-grained granular material. 
Table I. Description of Snow Used in the Tests

\begin{tabular}{|c|c|}
\hline Test series $\mathcal{N} o$. & Type of snow \\
\hline I & New snow \\
\hline 2 & $\begin{array}{l}\text { Depth hoar } \\
\text { Granular }\end{array}$ \\
\hline 3 & $\begin{array}{l}\text { Depth hoar } \\
\text { New snow }\end{array}$ \\
\hline 4 & $\begin{array}{l}\text { Depth hoar } \\
\text { Granular }\end{array}$ \\
\hline 5 & $\begin{array}{l}\text { Depth hoar } \\
\text { Granular }\end{array}$ \\
\hline 6 & $\begin{array}{l}\text { Depth hoar } \\
\text { New snow }\end{array}$ \\
\hline $7-8$ & $\begin{array}{l}\text { Depth hoar } \\
\text { Granular } \\
\text { New snow }\end{array}$ \\
\hline 9 & Depth hoar \\
\hline 10-1 3 & $\begin{array}{l}\text { Depth hoar } \\
\text { Granular } \\
\text { Mill waste }\end{array}$ \\
\hline 14 & $\begin{array}{l}\text { Depth hoar } \\
\text { Granular } \\
\text { Mill waste }\end{array}$ \\
\hline I5 & $\begin{array}{l}\text { Granular } \\
\text { Mill waste }\end{array}$ \\
\hline $16-17$ & $\begin{array}{l}\text { Depth hoar } \\
\text { Granular } \\
\text { Mill waste }\end{array}$ \\
\hline
\end{tabular}
Sieving with square meshes percentage finer than

\begin{tabular}{|c|c|c|c|c|c|}
\hline$I \cdot O O$ & $I \cdot 4^{I}$ & $\begin{array}{l}\mathrm{mm} . \\
2 \cdot 0 \mathrm{o}\end{array}$ & $2 \cdot 82$ & $4 \cdot 00$ & No. of days stored \\
\hline - & - & - & - & - & I \\
\hline $\begin{array}{r}4 \\
18\end{array}$ & $\begin{array}{r}7 \\
97\end{array}$ & $\begin{array}{r}43 \\
\text { 100 }\end{array}$ & $\underline{95}$ & 100 & $\begin{array}{c}2 \\
60\end{array}$ \\
\hline $\begin{array}{l}\text { I5 } \\
99\end{array}$ & $\begin{array}{r}32 \\
100\end{array}$ & 69 & 99 & 100 & $\begin{array}{c}\text { I5 } \\
2\end{array}$ \\
\hline $\begin{array}{l}\text { I7 } \\
65\end{array}$ & $\begin{array}{l}36 \\
95\end{array}$ & $\begin{array}{r}65 \\
100\end{array}$ & 93 & 100 & $\begin{array}{l}18 \\
21\end{array}$ \\
\hline $\begin{array}{l}2 \mathrm{I} \\
85\end{array}$ & $\begin{array}{l}44 \\
99\end{array}$ & $\begin{array}{r}74 \\
\text { 100 }\end{array}$ & $\underline{95}$ & I00 & $\begin{array}{l}30 \\
33\end{array}$ \\
\hline $\begin{array}{l}19 \\
87\end{array}$ & $\begin{array}{l}4 \mathrm{I} \\
97\end{array}$ & $\begin{array}{r}74 \\
100\end{array}$ & 99 & 100 & $\begin{array}{c}36 \\
4\end{array}$ \\
\hline $\begin{array}{l}24 \\
80\end{array}$ & $\begin{array}{l}49 \\
98\end{array}$ & $\begin{array}{r}77 \\
100\end{array}$ & $9^{8}$ & 100 & $\begin{array}{l}3^{8-39} \\
4^{1-4^{2}}\end{array}$ \\
\hline 84 & 97 & 100 & - & - & $5^{-6}$ \\
\hline 20 & 50 & 84 & $9^{8}$ & 100 & $5^{8}$ \\
\hline $\begin{array}{l}19 \\
80\end{array}$ & $\begin{array}{r}43 \\
\text { I00 }\end{array}$ & $\underline{79}$ & I00 & 二 & $\begin{array}{l}68-69 \\
60-61\end{array}$ \\
\hline 100 & - & - & - & - & $\mathrm{I}-4$ \\
\hline $\begin{array}{l}19 \\
80\end{array}$ & $\begin{array}{r}43 \\
\text { I00 }\end{array}$ & 79 & 100 & 二 & $\begin{array}{l}75 \\
67\end{array}$ \\
\hline 100 & - & - & - & - & I \\
\hline 80 & 100 & - & - & - & IOI \\
\hline 100 & - & 一 & - & - & I \\
\hline 19 & 43 & 79 & 100 & - & $84-86$ \\
\hline 80 & 100 & 二 & 二 & 二 & $66-68$ \\
\hline
\end{tabular}

The new snow used in the compaction tests was stored for one day in series 3 and 6 . In series 6 to 8 the new snow was stored for up to 6 days. Microscopic inspection showed that most of the snow particles still had a shape close to their original one, in spite of the long storage time. Granular snow originated either from settled snow in the natural snow cover or from new snow aged in the cold room. The mill waste was generally much more fine-grained than any of the snow collected from the natural snow cover. The particle size averaged about $\mathrm{o} \cdot \mathrm{I} \mathrm{mm}$.

When a mixture of two different snow types was studied, the following proportions were generally used: $0: 100,10: 90,30: 70,50: 50,70: 30,90: 10$ and 100:0 (except in test series I and 2).

\section{Agcuracy of Observations}

Usually, only one observation was carried out per specimen on density, cone hardness and shear strength. When hardness exceeded about $2 \mathrm{~kg} . / \mathrm{cm} .{ }^{2}$ as it usually did at maximum compaction, three observations were carried out with the drop cone. It was considered, in this case, that one reading did not disturb the specimen sufficiently to influence the other readings.

In order to check the accuracy of the measurements a test was carried out at $-9.5^{\circ} \mathrm{C}$. on a snow mixture consisting of ro per cent mill waste, 60 per cent granular snow and $3^{\circ}$ per cent depth hoar. The specimens were prepared and observed as described above. Eight specimens were prepared by "one-blow compaction", and another five by "maximum compaction". The observed mean values of the density and cone-hardness and information on dispersion are given in Table II. The results indicate that the specimens were prepared (mixed in desired proportions and compacted) quite uniformly. As the variation between 
Table II. An Example Showing the Dispersion of Observed Density and Hardness Values in Repeated Tests

$n$ is the number of observations per specimen

\begin{tabular}{|c|c|c|c|c|c|}
\hline \multirow[b]{2}{*}{$\begin{array}{l}\text { Method of } \\
\text { compaction }\end{array}$} & \multirow[b]{2}{*}{$\begin{array}{c}\text { Number of } \\
\text { specimens }\end{array}$} & \multicolumn{2}{|c|}{ Density } & \multicolumn{2}{|c|}{ Cone hardness } \\
\hline & & $\begin{array}{r}\text { Mean } \\
\text { g. } / \mathrm{cm} .^{3}\end{array}$ & $\begin{array}{l}\text { Standard } \\
\text { deviation }\end{array}$ & $\begin{array}{c}\text { Mean } \\
\mathrm{kg} . / \mathrm{cm}^{2}\end{array}$ & $\begin{array}{l}\text { Standard } \\
\text { deviation }\end{array}$ \\
\hline One blow & 8 & $\begin{array}{c}0.576 \\
(n=\mathrm{I})\end{array}$ & $0.0043^{*}$ & $\begin{array}{c}3 \cdot 14 \\
(n=1)\end{array}$ & $0.28 *$ \\
\hline Maximum & 5 & $\begin{array}{c}0.634 \\
(n=\mathrm{I})\end{array}$ & $0 \cdot 0048 *$ & $\begin{array}{c}6 \cdot 76 \\
(n=1)\end{array}$ & $\begin{array}{l}0 \cdot 90^{*} \\
2 \cdot 3{ }^{\dagger} \dagger\end{array}$ \\
\hline
\end{tabular}

specimens was quite small, it was assumed that the hardness of a given snow mixture could be determined with the desired accuracy from one specimen only. The spread of single values about the means for the maximum compaction series shown in Table II was slightly greater than that in most other test series. The coefficient of variation (standard deviation of single observations divided by the mean and expressed as a percentage) averaged 28 per cent for five specimens. Values between 20 and 25 per cent were usually found. The distribution of single values around the mean for each specimen did not differ significantly from a normal distribution (95 per cent confidence level).

The observations of shear strength were sometimes very inconsistent. Occasional disturbance of the specimen when the vane was forced into it and the fact that the torque wrench and vane were operated manually are the probable reasons. In a few cases, where it was obvious that the specimen had been disturbed, the shear strength value observed was excluded. No attempt was made, therefore, to study the dispersion of shear strength values, and the inconsistency of the shear strength observations was taken into consideration in the interpretation of the results.

\section{Test Results}

\section{Tests at Constant Temperature $\left(-9 \cdot 5^{\circ} \mathrm{C}\right.$.)}

Eight test series were carried out to study the dependence of density and hardness on the snow mixture. In series $I$ to 7 only two snow types were mixed at one time. In series 8 an attempt was made to imitate the change in the composition of the snow cover that might occur during the course of the winter under natural conditions in Sweden and eastern Canada.

As density was found to be reproducible for tests carried out under the same conditions of preparation, it was considered that plotting the results on a graph would be adequate for the analysis of the density observations. This has been done in Figure 3 .

The cone hardness values were more dispersed (Table II). Regression analysis was used, therefore, to analyse the cone hardness observations. Table III shows regression functions, computed according to the least-square method, and the standard deviation of single values from each regression line.

For test series 2 and 3 the observations on one-blow compaction were too few for a regression analysis. For series 8 the single tests were numbered from $\mathrm{I}$ to 8 , indicating increasing content of older and more coarse-grained snow. The functions in Table III are shown graphically in Figure 4.

\section{Maximum compaction}

The densities for the "pure" (unmixed) snow types ranged from $0.5 \mathrm{I}$ to $0.54 \mathrm{~g} . / \mathrm{cm} .{ }^{3}$ for depth-hoar snow, 0.54 to 0.58 for granular, and 0.45 to 0.58 for new snow. The values for the new snow fell within the range of values reported by Williams (1958) for a great number of measurements, indicating that the new snow samples used in these tests were not extreme 
a) MAXIMUM COMPACTION
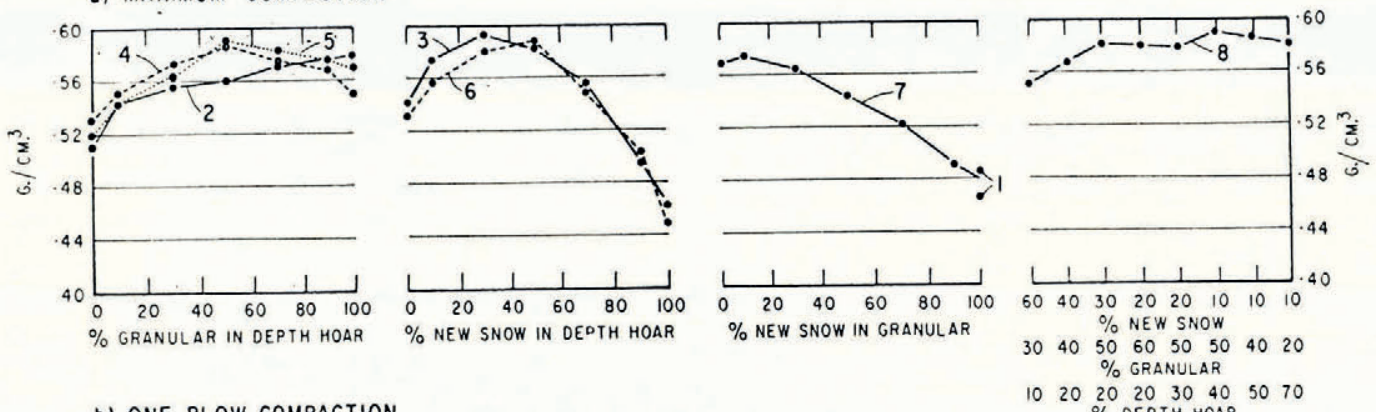

b) ONE BLOW COMPACTION
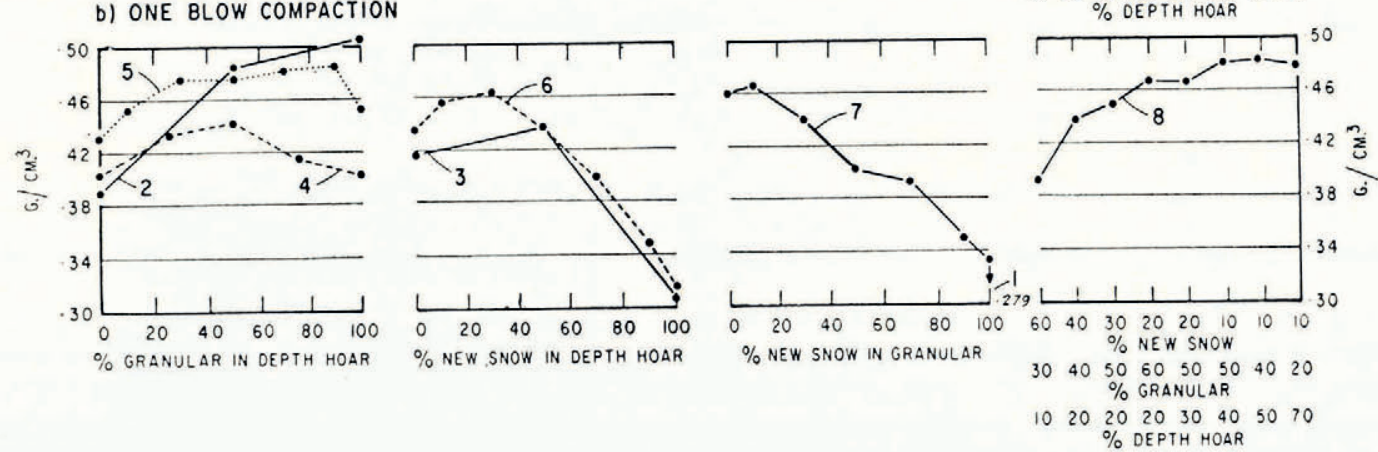

Fig. 3. Density versus different tvpes of snow and snow mixtures

Table III. Regression Functions $f(H)$ and the Standard Deviation of Single Values from the Regressions. Cone hardness $\left(H\right.$ KG. $/$ cm. $\left.^{2}\right)$ vs. Different Snow Mixtures

\begin{tabular}{|c|c|c|c|c|c|}
\hline \multirow[t]{2}{*}{$\begin{array}{l}\text { Series } \\
\text { No. }\end{array}$} & \multirow[t]{2}{*}{$\begin{array}{l}\text { Type of } \\
\text { compaction }\end{array}$} & \multicolumn{3}{|c|}{$\begin{array}{l}\text { Values of constants in the equation } \\
\qquad f(H)=a+b x+c x^{2}\end{array}$} & \multirow[t]{2}{*}{$\begin{array}{l}\text { Standard } \\
\text { deviation }\end{array}$} \\
\hline & & $a$ & $b \times 10^{2}$ & $c \times 10^{4}$ & \\
\hline 2 & maximum & $3 \cdot 16$ & $6 \cdot 14$ & $-7 \cdot 5^{0}$ & 0.59 \\
\hline 3 & maximum & $5 \cdot 54$ & $18 \cdot 35$ & $-14 \cdot 22$ & $I \cdot I I$ \\
\hline 4 & $\begin{array}{l}\operatorname{maximum} \\
\text { one blow }\end{array}$ & $\begin{array}{l}4 \cdot 24 \\
0 \cdot 82\end{array}$ & $\begin{array}{r}10.28 \\
0.68\end{array}$ & $\begin{array}{l}-7 \cdot 29 \\
0\end{array}$ & $\begin{array}{l}I \cdot 46 \\
0 \cdot 17\end{array}$ \\
\hline 5 & $\begin{array}{l}\operatorname{maximum} \\
\text { one blow }\end{array}$ & $\begin{array}{l}4 \cdot 24 \\
1 \cdot 05\end{array}$ & $\begin{array}{l}3 \cdot 98 \\
1 \cdot 28\end{array}$ & $\begin{array}{l}\text { o } \\
\text { o }\end{array}$ & $\begin{array}{l}I \cdot 42 \\
0 \cdot 34\end{array}$ \\
\hline 6 & $\begin{array}{l}\operatorname{maximum} \\
\text { one blow }\end{array}$ & $\begin{array}{l}3 \cdot 5^{0} \\
1 \cdot 07\end{array}$ & $\begin{array}{r}17 \cdot 57 \\
0 \cdot 26\end{array}$ & $-{ }_{0}^{-12} \cdot 4^{I}$ & $\begin{array}{l}\mathrm{I} \cdot 88 \\
\mathrm{O} \cdot \mathrm{I} 4\end{array}$ \\
\hline 7 & $\begin{array}{l}\operatorname{maximum} \\
\text { one blow }\end{array}$ & $\begin{array}{l}9 \cdot 25 \\
2 \cdot 57\end{array}$ & $\begin{array}{l}-3 \cdot 60 \\
-1 \cdot 23\end{array}$ & $\begin{array}{l}3 \cdot 94 \\
\text { o }\end{array}$ & $\begin{array}{l}2 \cdot 34 \\
0 \cdot 10\end{array}$ \\
\hline 8 & $\begin{array}{l}\text { maximum } \\
\text { one blow }\end{array}$ & $\begin{array}{l}9 \cdot 08 \\
I \cdot 71\end{array}$ & $\begin{array}{l}9 \cdot 37 \\
7 \cdot 74\end{array}$ & $-\mathrm{I} 82 \cdot 5$ & $\begin{array}{l}2 \cdot 72 \\
0 \cdot 21\end{array}$ \\
\hline
\end{tabular}

Independent variable $x$

percentage granular in depth hoar percentage new snow in depth hoar percentage granular in depth hoar percentage granular in depth hoar percentage new snow in depth hoar percentage new snow in granular test number

in their compactibility properties. In later test series (No. I 2 and 15 ) the density of mill waste was found to be $0 \cdot 5^{6}$ to $0 \cdot 5^{8}$ at maximum compaction.

Mixing different types of snow generally resulted in a density higher than that of any of the components. These tendencies seem to be more pronounced the greater the range of particle size. The values for series 8 , which was supposed to be an imitation of the natural snow cover during the course of a winter, ranged between 0.55 and 0.59 and showed little variation with the change in mixture. 
o) MAXIMUM COMPACTION
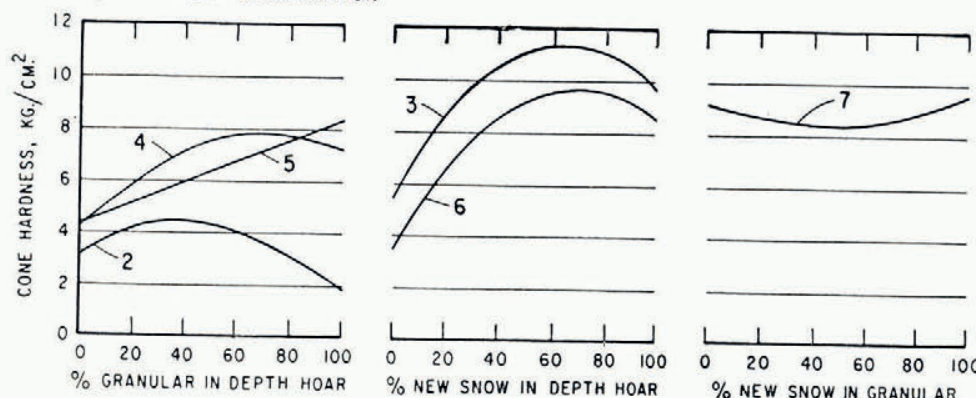

b) ONE BLOW COMPACTION
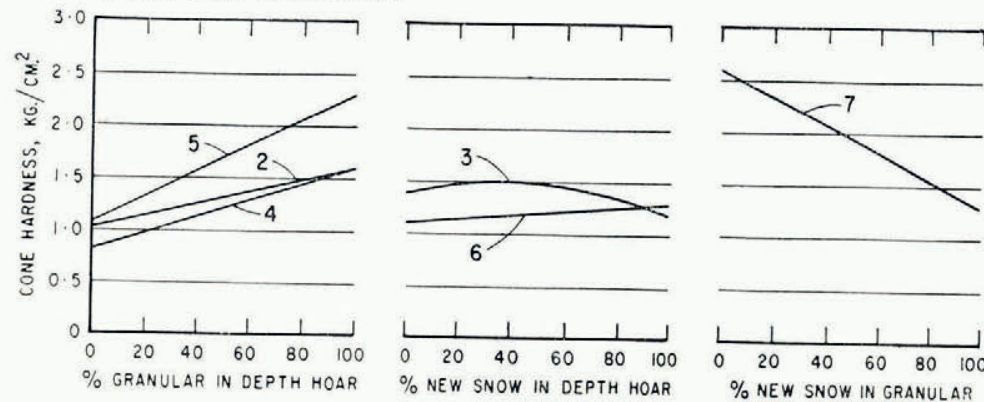

Fig. 4. Cone hardness versus type and mixlure of snow

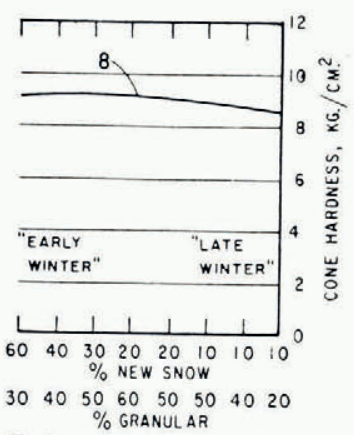

$10 \quad 20 \quad 20 \quad 20 \quad 30 \quad 40 \quad 50 \quad 70$ $\%$ DEPTH HOAR

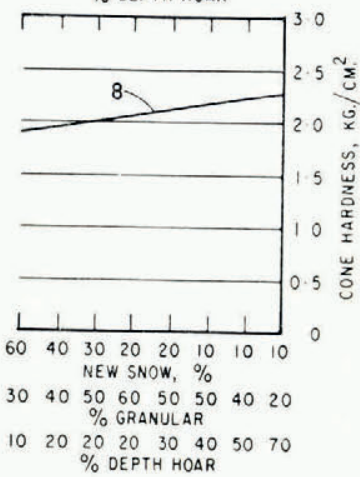

The cone hardness for the "pure" snow types ranged from $3 \cdot 0$ to $5 \cdot 5 \mathrm{~kg} . / \mathrm{cm} .^{2}$ for depthhoar snow, 7 to $9 \cdot 5$ for fine-grained granular snow and $8 \cdot 5$ to $1 \mathrm{I} \cdot 7$ for new snow. The lowest value, $2 \cdot 0 \mathrm{~kg} . / \mathrm{cm}^{2}$ was obtained for coarse-grained granular snow (series 2). For mill waste the hardness values were between 20 and $50 \mathrm{~kg} . / \mathrm{cm}^{2}$ (series 12 and $\mathrm{I}_{5}$ ). All mixtures including 50 per cent or more of fine granular snow or new snow fell in the range 7 to $1 \mathrm{rg} . / \mathrm{cm} .^{2}$. The new snow caused a greater increase in hardness than fine granular snow when mixed with depth hoar. The higher the percentage of grains finer than I $\cdot 0 \mathrm{~mm}$. (Table I), the higher the hardness when new snow or granular snow was mixed with depth-hoar snow. Series 8 (imitating the change in the natural snow cover during a winter) did not reveal any significant
trend.

\section{One-blow compaction}

Densities ranged from 0.39 to $0.43 \mathrm{~g} . / \mathrm{cm} .^{3}$ for depth hoar, 0.40 to 0.48 for the finegrained granular snow (o.5o for the coarse granular snow in series 2$), 0.28$ to 0.33 for new snow and 0.36 to 0.42 for mill waste (series 12 and 15 ).

As for maximum compaction, mixing of snow resulted in a density higher than the average of the densities of the single components and was more pronounced the greater the range of particle size. Series 8 showed an increase in density with increased content of granular and depth-hoar snow; according to the author's experience, the absolute values and the trend are very much the same as those obtained in the field with one-pass compaction with light equipment (rollers or drags) used for snow-road preparation.

The cone hardness for the pure snow types ranged from 0.9 to $\mathrm{I} \cdot 4 \mathrm{~kg} . / \mathrm{cm} .{ }^{2}$ for depth hoar, I. 6 to $2 \cdot 6$ for granular snow, 0.9 to $\mathrm{I} \cdot 2$ for new snow and $\mathrm{I} \cdot 0$ to $2 \cdot 6$ for mill waste. The 
positive effect on hardness by mixing can still be identified but is much less pronounced compared with the effect on snow compacted to maximum. The hardness values for series 8 did not show any significant trend.

\section{Miscellaneous tests and calculations}

In Figure 5 the ratio of maximum to one-blow compaction for density and cone hardness is plotted. The main result is that the higher the content of new snow, the greater the relative gain in hardness and density by compacting the snow to maximum compared to one-blow compaction. For pure new snow the ratio for cone hardness fell between 7 and 8 ; for mill waste values exceeding ro were found.
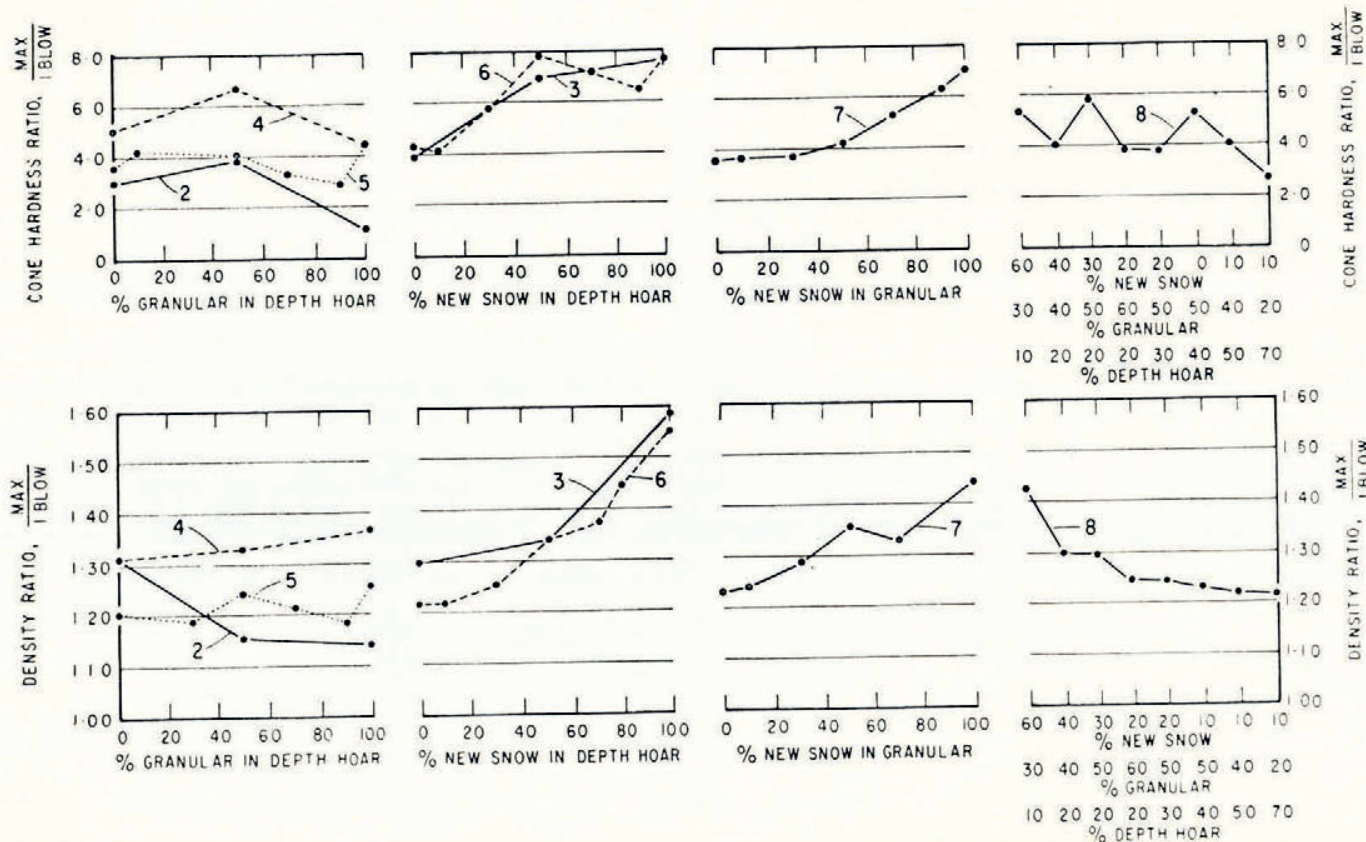

Fig. 5. Relative increase in hardness and density from one blow to maximum compaction for various snow types and mixtures

In Figure 6, the loose and the "relative" density are plotted. Loose density is that obtained by placing snow in cylinders without compaction; relative density is the ratio between the density of maximum compaction and loose density. It is sometimes used in soil mechanics to describe the qualitative behaviour of soils. The loose density ranged from $0.3^{2}$ to $0.39 \mathrm{~g} . / \mathrm{cm} .{ }^{3}$ for depth hoar, 0.23 to 0.40 for granular and 0.16 to 0.19 for new snow. A slight positive effect on the loose density was obtained when mixing different types of snow. The relationships between relative density and snow mixture follow the same pattern as the ratio of maximum density to one-blow density in Figure 5. No relationship was found between relative density and cone hardness.

Some tests were carried out at $-9 \cdot 5^{\circ} \mathrm{C}$. to determine the dependence of cone hardness on density. The results of these tests are shown in Figure 7 . The relationship between the logarithm of cone hardness and the density was found to be approximately linear, that is

$$
\log H=a \rho+b
$$

where $H$ is the cone hardness in $\mathrm{kg} . / \mathrm{cm}^{2}, \rho$ is the density in $\mathrm{g} \cdot / \mathrm{cm} .^{3}, a$ is the slope of the line 

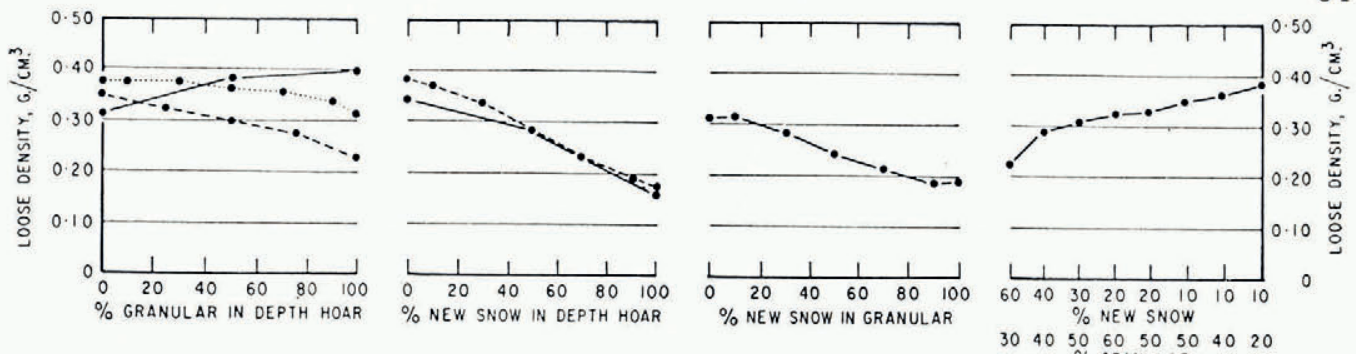

$3040 \quad 50 \quad 60 \quad 50 \quad 50 \quad 40 \quad 20$

$\%$ GRANULAR

I0 $20 \quad 20 \quad 20 \quad 30 \quad 40 \quad 50 \quad 70$

$\%$ DEPTH HOAR
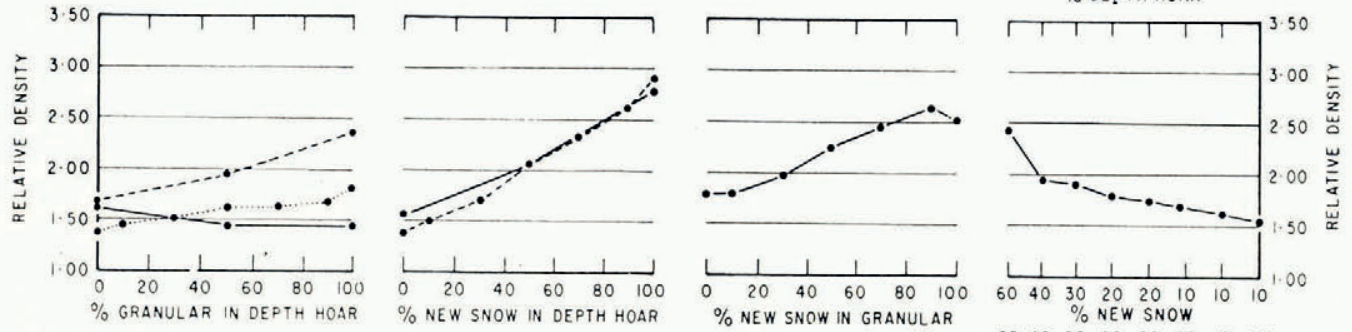

$\begin{array}{lllllllll}30 & 40 & 50 & 60 & 50 & 50 & 40 & 20\end{array}$ $\%$ GRANULAR

$\begin{array}{llllllll}10 & 20 & 20 & 20 & 30 & 40 & 50 & 70\end{array}$ $\%$ DEPTH HOAR

Fig. 6. Loose and relative density for various snow types and mixtures

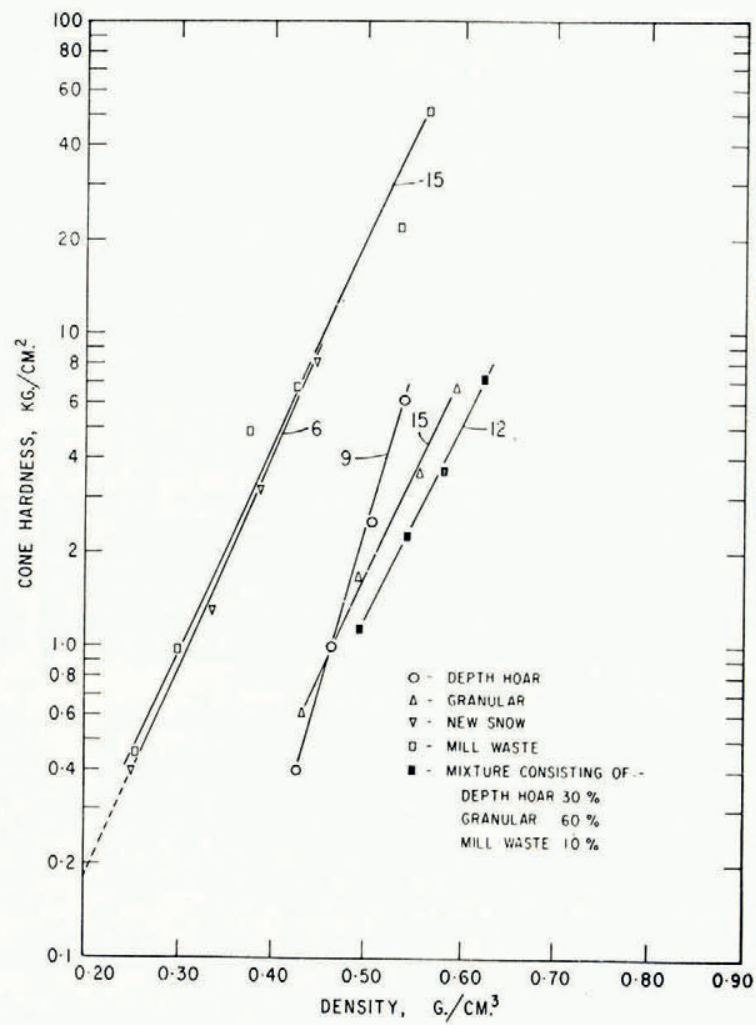

Fig. 7. Logarithm of cone hardness versus density 
and $b$ is a constant depending on the type and mixture of snow. The values of $a$ and $b$ obtained in the tests for different types of snow are shown in Table IV.

Table IV. Experimental Values of $a$ and $b$ in the Formula

\begin{tabular}{|c|c|c|c|c|c|c|}
\hline \multirow[b]{3}{*}{$\begin{array}{c}\text { Series } \\
\text { No. }\end{array}$} & \multicolumn{4}{|c|}{$\log H=a \rho+b$} & \multirow{2}{*}{\multicolumn{2}{|c|}{ Value of }} \\
\hline & & Type & snow & & & \\
\hline & $\begin{array}{c}\text { Depth } \\
\text { hoar } \\
\text { per cent }\end{array}$ & $\begin{array}{l}\text { Granular } \\
\text { per cent }\end{array}$ & $\begin{array}{c}\text { New } \\
\text { snow } \\
\text { per cent }\end{array}$ & $\begin{array}{c}\text { Mill } \\
\text { waste } \\
\text { per cent }\end{array}$ & $a$ & $b$ \\
\hline 6 & - & 一 & IOO & - & $6 \cdot 76$ & $-2 \cdot 09$ \\
\hline 9 & 100 & - & - & - & $10.8 \mathrm{I}$ & $-5.0 \mathrm{I}$ \\
\hline 12 & 30 & 60 & - & 10 & $5 \cdot 75$ & $-2 \cdot 75$ \\
\hline 15 & - & - & - & 100 & $6 \cdot 23$ & $-\mathrm{I} \cdot 84$ \\
\hline 15 & - & 100 & - & - & $6 \cdot 5^{2}$ & $-3 \cdot 04$ \\
\hline
\end{tabular}

In Figure 8 all pairs of observations on shear strength and cone hardness carried out at $-9 \cdot 5^{\circ} \mathrm{C}$. are plotted. The spread of the observations was so great that any definite influence of snow type on the relationship between shear strength and cone hardness was not revealed.

\section{Tests at different temperatures}

For one set of tests the snow was taken into the cold room and stored until it reached about the same temperature as the air there. Specimens were then prepared, left to harden for $24 \mathrm{hr}$. and their properties measured. The temperature was kept constant (within $\pm \mathrm{I}^{\circ} \mathrm{C}$. of that chosen) during the whole procedure. This type of test was done at $-\mathrm{I}^{\circ},-9.5^{\circ}$ and

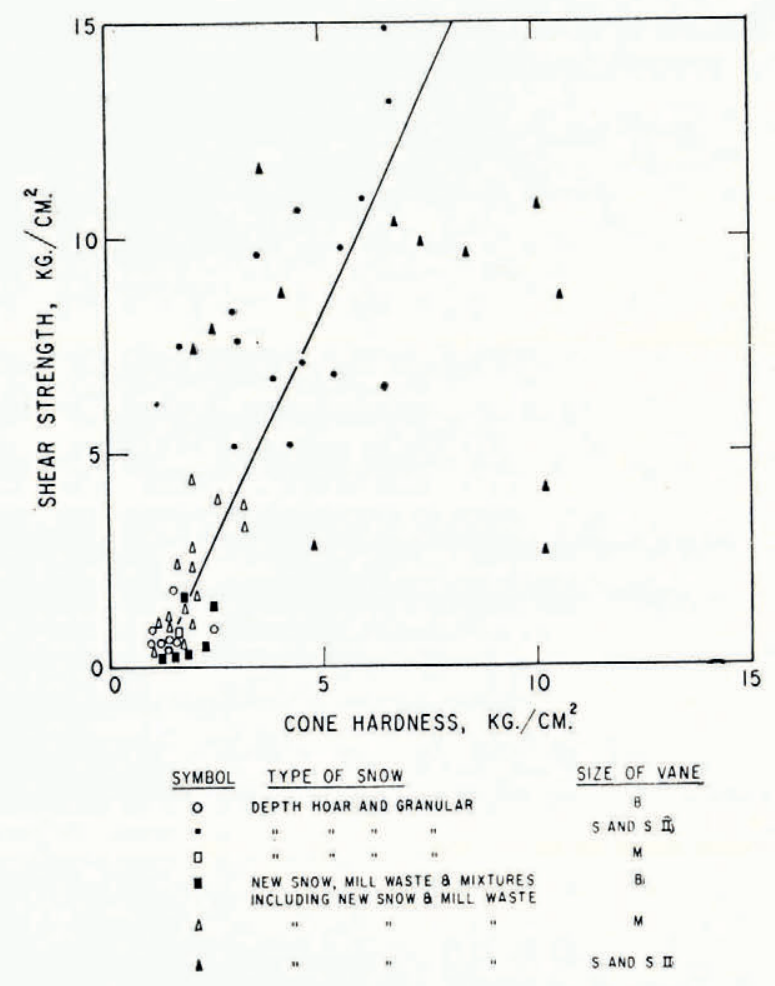

Fig. 8. Shear strength versus cone hardness for tests carried out at $-9 \cdot 5^{\circ} \mathrm{C}$. 
$-23^{\circ} \mathrm{C}$. As the tests were carried out in two different cold rooms, there was some difference in the relative humidity at these three temperatures; at $-\mathrm{I}^{\circ}$ and $-23^{\circ} \mathrm{C}$. it was 65 to 70 per cent and at $-9.5^{\circ} \mathrm{C}$., less than io per cent.

The density and cone hardness obtained by maximum and one-blow compaction are plotted in Figure 9 for different types of snow. The compacted density showed very little
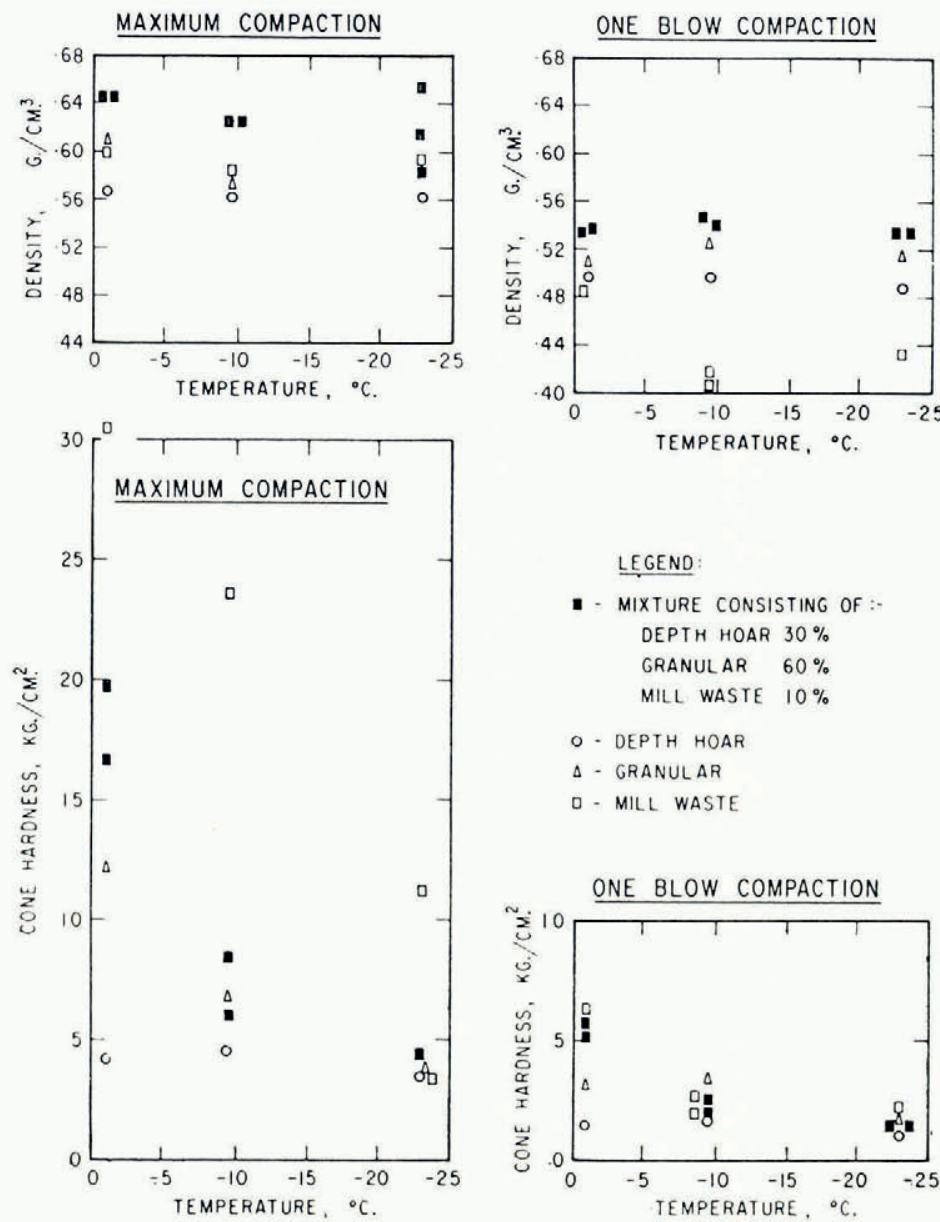

$$
\begin{aligned}
& \text { LEGEND: } \\
& \text { - MIXTURE CONSISTING OF :- } \\
& \text { DEPTH HOAR } 30 \% \\
& \text { GRANULAR } 60 \% \\
& \text { MILL WASTE } 10 \% \\
& \text { - DEPTH HOAR } \\
& \text { D- GRANULAR } \\
& \text { D- MILL WASTE }
\end{aligned}
$$

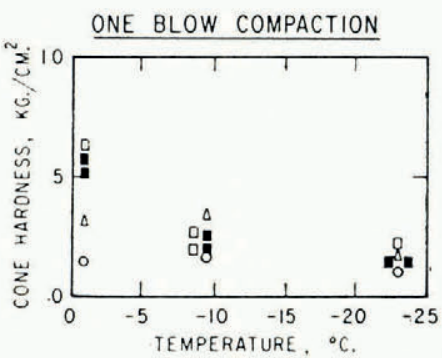

Fig. 9. Density and cone hardness versus temperature $24 \mathrm{hr}$. after compaction

temperature dependence for either maximum or one-blow compaction. One could possibly identify a very small but insignificant trend towards higher densities at higher temperatures. The effect of mixing on compacted density was very marked, confirming the results shown in Figure 3. Cone hardness generally showed a marked drop with decreasing temperature. The difference between varying types of snow was more pronounced at high temperatures. The hardness of the depth-hoar snow was hardly affected by the temperature, but the mill waste was very sensitive. The cone hardness of the fine-grained mill waste was much higher than the hardness of any type of snow collected from the natural snow cover. In general, the results in Figure 9 do not contradict the main conclusions drawn from Figures 3 to 5 . 
The relationship between cone hardness and density at different temperatures is shown in Figure 10 for tests done in the way described above at $-\mathrm{I}^{\circ},-9.5^{\circ}$ and $-23^{\circ} \mathrm{C}$. with a mixture of mill waste (ro per cent), granular snow (6o per cent) and depth-hoar snow (3o per cent). With the same mixture the following tests were also carried out: One set of specimens was compacted at $-18^{\circ} \mathrm{C}$.; the temperature was then raised to $-2^{\circ} \mathrm{C}$. over a period of $4 \mathrm{hr}$. and kept constant for about $20 \mathrm{hr}$. Another set of specimens was compacted at $-\mathrm{I}^{\circ} \mathrm{C}$.; the temperature was then lowered to $-23^{\circ} \mathrm{C}$. over a period of $4 \mathrm{hr}$. and kept constant for about $20 \mathrm{hr}$. At the end of the 24-hr. period, cone hardness and density were measured.

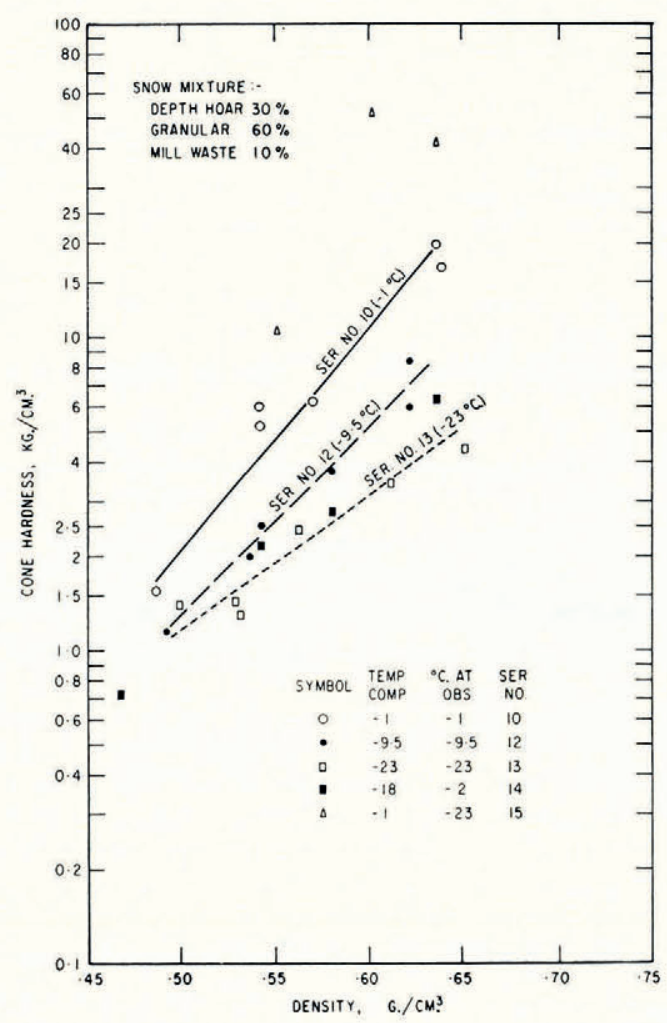

Fig. Io. Compaction tests at different temperatures

The results of these tests also are plotted in Figure io. The specimens compacted at $-18^{\circ}$ and kept at $-2^{\circ} \mathrm{C}$. showed only a third to a half the cone hardness of the specimens compacted and maintained at a temperature of $-\mathrm{I}^{\circ} \mathrm{C}$. The specimens compacted at $-\mathrm{I}^{\circ} \mathrm{C}$. and kept at $-23^{\circ} \mathrm{C}$. had a cone hardness io to $\mathrm{I} 5$ times as great for maximum compaction and about 7 times as great for one-blow compaction as the hardness obtained for the specimens compacted and kept at $-23^{\circ} \mathrm{C}$. These results help to explain why it is difficult to get consistent hardnesstemperature-density relationships from field tests with full-scale field equipment.

A second study on the influence of temperature on the strength properties of snow was done in the following way. Ten specimens were compacted at $-9 \cdot 5^{\circ} \mathrm{C}$., five of them by oneblow compaction and five by maximum compaction. They were then allowed to harden for 24 to 27 days at $-9.5{ }^{\circ} \mathrm{C}$. The specimens were brought into another cold room and kept there for 24 to $32 \mathrm{hr}$. at given temperatures before the cone hardness (all specimens) and shear strength (only for one-blow compaction) were measured. The longer time of storage at 
$-9 \cdot 5^{\circ} \mathrm{C}$. was done in order to reach such a degree of bonding between the particles that only a minor increase should take place when the specimens were stored at different temperatures. The influence of temperature on the degree of bonding (on the age hardening) should thus be eliminated to a great extent, and the test should show the temperature dependence of the strength properties of "mature" snow (with respect to age hardening).

Figure I I shows the results of this test. The cone hardness and shear strength were strongly influenced by temperature but the trend was the reverse of that obtained for snow that had hardened for only $24 \mathrm{hr}$. after compaction.
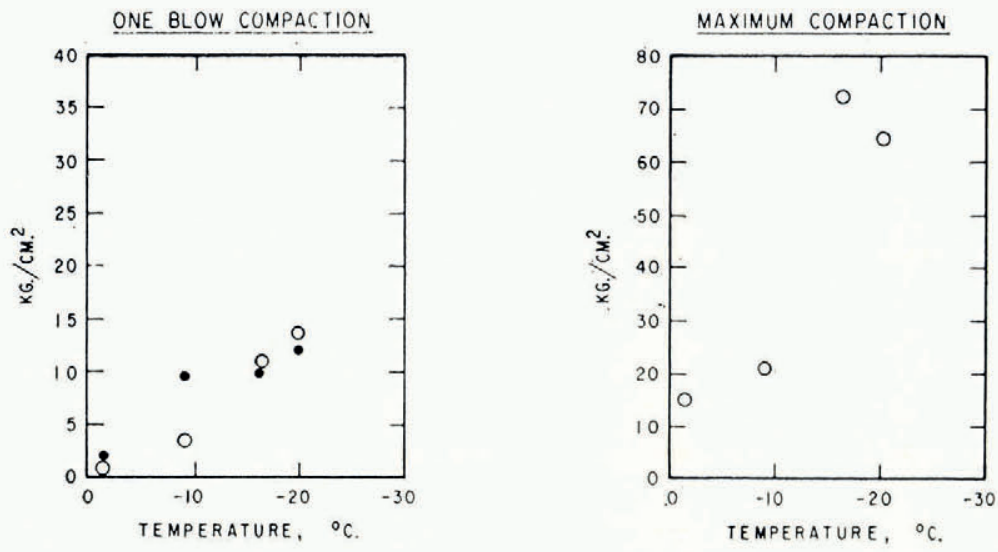

$$
\begin{aligned}
& \text { LEGEND } \\
& \text { O CCNE HARDNESS } \\
& \text { - SHEAR STRENGTH }
\end{aligned}
$$

Fig. II. Cone hardness and shear strength versus temperature for specimens "age hardened" for 24 to 27 days at $-9 \cdot 5 C^{\circ}$. (Serial No. 16 )

\section{Summary and Conclusions}

Compaction of different types and mixtures of snow was carried out with a small compactor. The snow used in the tests was collected from the natural snow cover and stored in a cold room for a length of time varying from a few hours to about three months. Waste from an ice milling machine was also used. After compaction the specimens were allowed to harden for at least $24 \mathrm{hr}$., when density, "cone hardness" and shear strength were measured. The aim of the study was to elucidate the influence of type and mixture of snow on these parameters. Most of the tests were carried out at a temperature of $-9.5{ }^{\circ} \mathrm{C}$. The results were as follows:

When the snow was compacted to maximum (for this type of compaction), densities between 0.55 and $0.60 \mathrm{~g} . / \mathrm{cm} .{ }^{3}$ were usually achieved, except for mixtures including more than one-third of new snow, for which the densities were lower. For snow collected from the natural cover, the highest cone values $\left(7\right.$ to $I \mathrm{I} \mathrm{kg} . / \mathrm{cm} .{ }^{2}$ ) were found for new snow and for mixtures including more than $5^{\circ}$ per cent of the new snow or fine-grained granular snow (Figs. 3 and 4). Considerably higher values were obtained for specimens prepared from very fine-grained mill waste.

When the snow was subject to lighter compaction (one-blow compaction) granular snow and mixtures including granular snow had a density and cone hardness higher than the other types of snow and mixtures.

The influence of temperature on density and hardness was also studied in the range from $-\mathrm{I}$ to $-23^{\circ} \mathrm{C}$. During the first $24 \mathrm{hr}$. after compaction cone hardness became considerably 
higher at high temperatures than at low ones. Fine-grained snow was much more sensitive than coarse-grained snow in this respect (Fig. 9). The highest hardness values were obtained when compaction was carried out at $-\mathrm{I}^{\circ} \mathrm{C}$. and the temperature then lowered to $-23^{\circ} \mathrm{C}$. For snow that was stored at $-9.5^{\circ} \mathrm{C}$. for almost a month after compaction and then kept for $24 \mathrm{hr}$. at different temperatures, cone hardness and shear strength increased considerably as the temperature decreased (Fig. I I).

This investigation has to be considered as a pilot study. The test material was quite limited, especially for the influence of temperature on hardness and density of snow. It has given, however, satisfactory answers to the questions that initiated the study. It has also shown that this type of study can give useful information on the properties of compacted snow.

\section{ACKNOWLedgements}

The author wishes to express his gratitude to the National Research Council of Canada for the award of a post-doctorate fellowship, which made it possible to carry out this investigation. Access to a well-equipped cold room has been especially appreciated. The author is also indebted to Mr. L. W. Gold and Mr. G. P. Williams for helpful criticism and guidance in preparing this report and to Mr. R. Ducharme for his assistance in measuring densities.

MS. received 6 August 1964

\section{REFERENGES}

Angervo, J. M. r95I. Snöundersökningar i Finland. Teknisk Tidskrift, Bd. 81, Ht. 34, p. 747-49.

Kingery, W. D., ed. 1963. Ice and snow; properties, processes, and applications: proceedings of a conference held at the Massachusetts Institute of Technology, February 12-16, 1962. Cambridge, Mass., The M.I.T. Press.

Williams, G. P. 1958. Compactibility of newly fallen snow in eastern Canada. Fournal of Glaciology, Vol. 3, No. 24, p. $257-60$. 